BBA 72385

\title{
MODIFICATION OF THE ERYTHROCYTE MEMBRANE BY A NON-SPECIFIC LIPID TRANSFER PROTEIN
}

\author{
P.F.H. FRANCK, J.M. DE REE, B. ROELOFSEN and J.A.F. OP DEN KAMP \\ Laboratory of Biochemistry, State University of Utrecht, Transitorium III, Padualaan 8, NL-3584 CH Utrecht (The \\ Netherlands)
}

(Received May 28th, 1984)

Key words: Phospholipid composition; Lipid-transfer protein; Cholesterol; (Human erythrocyte membrane)

The non-specific phospholipid transfer protein purified from bovine liver has been used to modify the phospholipid content and phospholipid composition of the membrane of intact human erythrocytes. Apart from an exchange of phosphatidylcholine between the red cell and PC-containing vesicles, the protein appeared to facilitate net transfer of phosphatidylcholine from the donor vesicles to the erythrocyte and sphingomyelin transfer in the opposite direction. Phosphatidylcholine transfer was accompanied by an equivalent transfer (on a molar basis) of cholesterol. An increase in phosphatidylcholine content in the erythrocyte membrane from 90 to $282 \mathrm{nmol}$ per $100 \mu$ l packed cells was observed. Phospholipase $C$ treatment of modified cells showed that all of the phosphatidylcholine which was transferred to the erythrocyte was incorporated in the lipid bilayer. The nonspecific lipid transfer protein used here appeared to be a suitable tool to modify lipid content and composition of the erythrocyte membrane, and possible applications of this approach are discussed.

\section{Introduction}

The localization of phospholipids in the human erythrocyte membrane has been studied in detail. Most of the methods used are based on a modification of the phospholipids (hydrolysis, coupling to reactive probe molecules), and it will be obvious that, as a result of such modifications, the bilayer structure can change which in turn may lead to erroneous interpretations of the data obtained (reviewed in Ref. 1). Recently, a relative mild and non-modifying technique was developed which is based on a one-for-one exchange of phospholipid molecules between two different membrane systems as mediated by phospholipid transfer proteins [2]. The approach has been worked out in detail, using the phosphatidylcholine specific transfer protein from bovine liver and was applied to study both the localization as well as the trans- bilayer mobility of $\mathrm{PC}$ in the human erythrocyte membrane [2-4].

It was of interest to investigate if the organization of other phospholipids in the erythrocyte membrane could be studied in a similar, non-destructive fashion and therefore we tried a procedure developed by Crain and Zilversmit [5] in which a nonspecific lipid transfer protein was used. Recently, several laboratories reported the purification of a nonspecific lipid transfer protein which showed a broad specificity towards various phospholipids and sterols as well as glycosphingolipids [6-11]. Application of this protein in phospholipid localization experiments showed, however, that in addition to the exchange of lipids a net transfer of lipids was facilitated by the protein $[9,12,13]$ which may hamper a straightforward interpretation of the results obtained in these studies. On the other hand, the multiple functions of this nonspecific 
lipid transfer protein offer the possibility to modulate, in a controlled fashion, the lipid composition of a membrane and provides an elegant tool to study the effects that such changes may have on membrane structure and function [14-17]. This report describes such modulations of both the content and composition of the lipids in the membrane of intact human erythrocytes, which may have relevance for the study of red cell abnormalities known to be associated with particular types of liver diseases.

\section{Materials and Methods}

Human red cells, $10 \mathrm{ml}$ of which were collected in $2.2 \mathrm{ml}$ of a solution containing $80 \mathrm{mM}$ sodium citrate/ $28 \mathrm{mM}$ citric acid/ $183 \mathrm{mM}$ glucose, were washed three times with buffer containing 280 $\mathrm{mM}$ sucrose $/ 10 \mathrm{mM} \mathrm{NaCl} / 1 \mathrm{mM}$ EDTA $/ 20 \mathrm{mM}$ glucose $/ 10 \mathrm{mM}$ Tris- $\mathrm{HCl}(\mathrm{pH} 7.4)$ which will be referred to as 'standard buffer' throughout. Unilamellar vesicles containing equimolar amounts of phospholipids (97\% phosphatidylcholine (PC) and $3 \%$ phosphatidic acid, molar ratio) and cholesterol were prepared and described elsewhere [3]. Nonspecific lipid transfer protein was purified from bovine liver according to Crain and Zilversmit [7], and stored at $-20^{\circ} \mathrm{C}$ in $100 \mathrm{mM}$ potassium phosphate/5 mM 2-mercaptoethanol/50\% glycerol (v/v) (pH 6.8). The nonspecific lipid transfer protein was dialyzed overnight against 300 volumes of standard buffer prior to use.

Incubation with transfer protein. Incubations were routinely performed at $37^{\circ} \mathrm{C}$ with gentle rotations. The mixture contained erythrocytes $(100 \mu 1$ packed cells corresponding to $390 \mathrm{nmol}$ phospholipid), unilamellar vesicles $(2.2 \mu \mathrm{mol}$ phospholipid) and were incubated with $25 \mu \mathrm{g}$ nonspecific lipid-transfer protein. In a number of experiments smaller amounts of erythrocytes and equivalent amounts of other constituents were used.

The final hematocrit was 33\%. After various incubation times, samples were taken from the mixture, diluted with a 6-fold volume of standard buffer and centrifuged at $2500 \times g$ for $5 \mathrm{~min}$. The erythrocytes were washed two times with standard buffer to remove residual vesicles and transfer protein and were extracted according to Rose and
Oklander [18]. Lipid extracts were analyzed for total amount of phospholipid [19] and cholesterol [20]. The content of different lipid species was analyzed after two-dimensional thin-layer chromatography [21].

Incubation with phospholipase $C$. Cells which had been pre-incubated with the nonspecific lipid transfer protein and vesicles which contained trace amounts of glycerol[ $\left[1{ }^{14} \mathrm{C}\right.$ )oleate $(40 \mathrm{cpm} / \mathrm{nmol}$ PC) and egg phosphatidyl $\left[N\right.$-methyl $\left.-{ }^{14} \mathrm{C}\right]$ choline (6 $\mathrm{cpm} / \mathrm{nmol}$ ) for $2 \mathrm{~h}$ as described above, were isolated by centrifugation and resuspended in a buffer containing $150 \mathrm{mM} \mathrm{NaCl} / 10 \mathrm{mM} \mathrm{CaCl}_{2} / 25 \mathrm{mM}$ glucose $/ 10 \mathrm{mM}$ Tris- $\mathrm{HCl}$ (pH 7.4). Purified phospholipase $\mathrm{C}$ from Bacillus cereus [22] was added (7.5 IU $/ 100 \mu \mathrm{l}$ packed cells) and incubation was performed at $37^{\circ} \mathrm{C}$ for $2 \mathrm{~h}$. Thereafter, cells were isolated, washed twice with the buffer described above, which contained $20 \mathrm{mM}$ EDTA and 20 $\mathrm{mM}$ o-phenanthrolinium chloride instead of $\mathrm{CaCl}_{2}$. Cells were extracted [18] and lipid extracts were separated by one-dimensional thin-layer chromatography on silicagel (60 HR) using hexane/ diethyl ether/acetic acid $(85: 15: 2, \mathrm{v} / \mathrm{v})$, as developing system. Radioactivity was measured from areas on the plates corresponding to glycerol trioleate, cholesteryl oleate and PC.

Incubations with phospholipase $\mathrm{C}$ were carried out also on erythrocytes which had been prelabeled (using the nonspecific lipid transfer protein) with $1-\left[{ }^{14} \mathrm{C}\right]$ palmitoyl-2-palmitoyl-sn-glycero3 -phosphocholine. In this case lipid extracts were separated by thin-layer chromatography using chloroform/methanol/25\% ammonia/water $(90: 54: 5.5: 5.5, \mathrm{v} / \mathrm{v})$ as developing system, and radioactivity was determined in areas corresponding to PC and diacylglycerols.

\section{Results}

When red cells, unilamellar vesicles and transfer protein were incubated under conditions described in Materials and Methods and in the legend to Fig. 1, net transfer of lipids from donor vesicles to erythrocytes occurs, as is shown by an increased phospholipid as well as cholesterol content of the cells. In control incubations without nonspecific lipid transfer protein, the amount of lipid in the erythrocyte did not alter. Cholesterol and phos- 


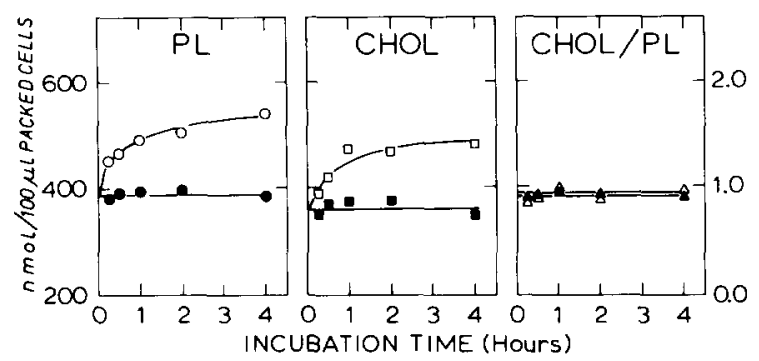

Fig. 1. Transfer of phospholipids and cholesterol to erythrocytes. Human erythrocytes were incubated with $\mathrm{PC} /$ cholesterol vesicles in the standard buffer at a hematocrit value of $33 \%$ and with gentle rotation at $37^{\circ} \mathrm{C}$. At time points indicated aliquots were taken, the erythrocytes were isolated by centrifugation and the total phospholipid content $(\bullet, O)$ and cholesterol content $(\square, \square)$ were determined. The incubations were carried out with (open symbols) and without (closed symbols) nonspecific lipid transfer protein and data are expressed as nmoles of phospholipid and cholesterol, respectively, per $100 \mu \mathrm{l}$ packed cells. The utmost right figure shows the molar ratio cholesterol/phospholipid.

pholipids are transferred in equimolar amounts, resulting in an unaltered cholesterol/phospholipid ratio of the intact erythrocyte throughout the incubation period. In general, no additional transfer was observed after the initial lipid level had been raised by $30-50 \%$.

Not only the total lipid content in the cell is altered by the action of the transfer protein, also the phospholipid composition of the membrane changes drastically. Table I shows how the absolute amount and relative content of the various phospholipid classes in the membrane of intact erythrocytes are modified by an incubation in the presence of unilamellar $\mathrm{PC} /$ cholesterol vesicles and nonspecific lipid transfer protein. The concentration of PC increases 3-fold, which value corresponds with an enhancement from 89.6 to 282.0 nmoles per $100 \mu \mathrm{l}$ packed cells, causing a change in relative composition of the other phospholipid classes. The effect of the incubation on the sphingomyelin content was also dramatic. The absolute amount of this phospholipid decreased with $42 \%$ from 92.2 nmoles to 53.4 nmoles per 100 $\mu 1$ packed cells, whereas on the other hand, the aminophospholipids, phosphatidylethanolamine and phosphatidylserine, declined hardly in content.

The data presented in Fig. 1 and Table I allow the conclusion that apart from exchange net transfer of lipids is a major process carried out by this transfer protein. Also exchange is stimulated, as can be concluded from the observation that the increase in specific radioactivity of PC in the erythrocyte is higher than expected from the net transfer of PC alone (data not shown). Thus, unlabeled PC and sphingomyelin move from the erythrocyte to the donor vesicles and radioactive

TABLE I

ALTERATIONS IN THE PHOSPHOLIPID COMPOSITION OF ERYTHROCYTES AFTER INCUBATION WITH NONSPECIFIC LIPID TRANSFER PROTEIN AND PC/CHOLESTEROL VESICLES

Absolute and relative phospholipid composition of erythrocytes incubated in the presence of $\mathrm{PC} /$ cholesterol vesicles with and without non-specific lipid transfer protein, under conditions described in the Materials and Methods. Isolated erythrocytes were extracted and the phospholipids were separated by two-dimensional TLC according to Broekhuyse [21]. The amounts of individual phospholipids were determined by phosphate analysis [19]. Data are expressed as nmol phospholipid P per $100 \mu 1$ packed cells (left) and as $\%$ of total phospholipid present (right). nsLTP, nonspecific lipid transfer protein; Sph, sphingomyelin; PE, phosphatidylethanolamine; PS, phosphatidylserine.

\begin{tabular}{|c|c|c|c|c|c|}
\hline & \multicolumn{3}{|l|}{ nmol } & \multicolumn{2}{|l|}{ \% } \\
\hline & $\begin{array}{l}- \text { nsLTP } \\
\text { mean } \pm \text { S.D. }\end{array}$ & $\begin{array}{l}+ \text { nsLTP } \\
\text { mean } \pm \text { S.D. }\end{array}$ & $\Delta$ & $\begin{array}{l}- \text { nsLTP } \\
\text { mean } \pm \text { S.D. }\end{array}$ & $\begin{array}{l}+ \text { nsLTP } \\
\text { mean } \pm \text { S.D. }\end{array}$ \\
\hline PC & $89.6 \pm 11.8$ & $282.0 \pm 0.2$ & +192.4 & $28.7 \pm 3.8$ & $61.3 \pm 0.2$ \\
\hline Sph & $92.2 \pm 6.4$ & $53.4 \pm 0.2$ & -38.8 & $29.5 \pm 2.1$ & $11.6 \pm 0.1$ \\
\hline $\mathrm{PE}$ & $87.8 \pm 6.2$ & $84.8 \pm 13.6$ & -3.0 & $28.1 \pm 2.0$ & $18.4 \pm 2.9$ \\
\hline PS & $42.2 \pm 13.8$ & $40.0 \pm 1.6$ & -2.2 & $13.5 \pm 4.4$ & $8.7 \pm 0.3$ \\
\hline Tot. & $311.8 \quad 38.2$ & $460.2 \quad 15.6$ & +148.4 & 100 & 100 \\
\hline
\end{tabular}


PC is transferred the other way round. Both processes result in a decrease of sphingomyelin and a net increase of phosphatidylcholine. That phosphatidylethanolamine and phosphatidylserine are not transferred, is understandable, because these phospholipids are predominantly located at the inside of the erythrocyte and are not accessible for the transfer protein [1,2]. Finally, cholesterol is transferred but in this case it is not certain whether the transfer is exclusively mediated by the nonspecific lipid transfer protein. A decrease in cholesterol/phospholipid molar ratio in the erythrocyte membrane is induced by the net transfer of PC, resulting in a concomitant increase in cholesterol/phospholipid molar ratio in the donor vesicle. As shown in various studies [23-25], such a difference in cholesterol/phospholipid ratio will be equilibrated by spontaneous transfer of cholesterol.

The composition of donor and acceptor membranes can have an effect on the direction and extent of the phospholipid transfer, as is illustrated by incubation of the red cells with the non-specific lipid transfer protein and vesicles consisting of variable amounts of $P C$ and sphingomyelin. Incubation of red cells, under identical conditions as described in Table I, with vesicles containing equimolar amounts of cholesterol and either PC alone, PC/sphingomyelin $(4: 5$, mole/mole), or sphingomyelin alone, resulted in shifts of the erythrocyte phospholipid compositions which resemble that of the donor vesicles. It is shown in Table I that in the absence of sphingomyelin in the donor system the absolute amount of this lipid in the erythrocytes decreases from 92.2 to 53.4 nmoles per $100 \mu \mathrm{l}$ packed cells, which results in a PC/ sphingomyelin ratio of 5.3. When donor vesicles are used which contain both PC and sphingomyelin $(4: 5 \mathrm{~mole} / \mathrm{mole})$ the $\mathrm{PC}$ content of the erythrocytes decreases ( 90.3 to 85.5 nmoles) and their sphingomyelin content increases ( 78.4 to 92.2 nmoles) upon incubation with nonspecific lipid transfer protein. By omission of $\mathrm{PC}$ from the donor vesicles, the loss of PC from the erythrocytes is even more pronounced (87.8 to 69.9 nmoles) whereas in this case a substantial enrichment of the erythrocytes with sphingomyelin is measured (from 80.9 to 149 nmoles $/ 100 \mu 1$ packed cells), which results in a final $\mathrm{PC} /$ sphingomyelin ratio of 0.5 . The small variations in the absolute values of initial sphingomyelin content have to be ascribed to differences in phospholipid composition of membranes from various donors. A change in the aminophospholipid content of the cells was, as previously noted, not significant under these conditions.

To distinguish whether the accumulation of the lipids in the erythrocytes is indeed due to the transfer activity of the nonspecific lipid transfer protein, inserting individual lipids in the red cell membrane, to fusion of lipid vesicles with erythrocytes or to contamination of donor vesicles which stick to erythrocytes, experiments were carried out using vesicles which were supplemented with non-exchangeable markers [13] as well as experiments which involve phospholipase $\mathrm{C}$ treatments. Triacylglycerols and cholesteryl esters are such lipids for which transfer proteins, in general, have no affinity, and thus 'transfer' of these components from donor to acceptor membrane system, may reflect a comparable amount of contaminated or fused vesicle phospholipid or cholesterol. In order to characterize the net transfer of lipids to the erythrocytes by the transfer protein, both non-exchangeable markers glycerol tri[ $\left[1-{ }^{14} \mathrm{C}\right]$ oleate and cholesteryl $\left[1{ }^{14} \mathrm{C}\right]$ oleate together with egg phosphatidyl $\left[N\right.$-methyl- $\left.{ }^{14} \mathrm{C}\right]$ choline as an exchangeable lipid were incorporated in egg $\mathrm{PC} /$ cholesterol vesicles. Incubation with erythrocytes and nonspecific lipid transfer protein were performed, the results of which are shown in Table II. The control incubations, containing only erythrocytes and vesicles, clearly demonstrate that the amount of PC originating from contaminated or fused vesicles is low, as can be determined from the amounts of the non-exchangeable markers glycerol trioleate and cholesteryl oleate. The radioactivity in the phosphatidylcholine fraction accumulated more, probably due to a spontaneous exchange of phospholipids, which is known to occur between donor and acceptor membranes, be it at a very low rate [26]. Incubation of red cells and vesicles in the presence of nonspecific lipid transfer protein considerably increased the amount of the non-exchangeable markers in the erythrocyte membranes. As is demonstrated in Table II, almost $25 \%$ of the total PC which is transferred to the red cells can be ascribed to contamination or 
TABLE II

TRANSFER OF PHOSPHATIDYLCHOLINE TO ERYTHROCYTES

Erythrocytes ( $30 \mu \mathrm{l}$ packed cells) were incubated for $2 \mathrm{~h}$ with unilamellar vesicles which contained in addition to equimolar amounts of egg PC and cholesterol, trace amounts of glycerol tri $\left[1-{ }^{14}\right.$ C $]$ oleate $(20 \mathrm{cpm} / \mathrm{nmol} \mathrm{PC})$, cholesteryl $\left[1-{ }^{14} \mathrm{C}\right] \mathrm{oleate}(40 \mathrm{cpm} / \mathrm{nmol} \mathrm{PC})$ and egg phosphatidyl $\left[N\right.$-methyl $\left.-{ }^{14} \mathrm{C}\right]$ choline $(6 \mathrm{cpm} / \mathrm{nmol} \mathrm{PC})$. Incubation conditions were as described in the legend to Fig. 1. Erythrocyte lipids were analyzed as described in Materials and Methods. Radioactivity measurements of individual lipids after thin-layer chromatographic separation revealed the amounts of total PC transferred as well as the amounts of glycerol trioleate and cholesteryl oleate. The latter values were used to calculate the extent of contamination of erythrocytes with adhering vesicles assuming that both cholesteryl oleate and glycerol trioleate are non-exchangeable markers. Data are expressed as nmoles PC.

\begin{tabular}{|c|c|c|c|}
\hline & \multirow{2}{*}{$\begin{array}{l}\text { Total PC } \\
\text { transferred }\end{array}$} & \multicolumn{2}{|c|}{ PC present as contamination based on } \\
\hline & & $\begin{array}{l}\text { Glycerol } \\
\text { trioleate }\end{array}$ & $\begin{array}{l}\text { Cholesteryl } \\
\text { oleate }\end{array}$ \\
\hline Vesicles + erythrocytes & $5.2 \pm 0.2$ & $2.0 \pm 0.2$ & $2.2 \pm 0.2$ \\
\hline \multicolumn{4}{|l|}{ Vesicles + erythrocytes } \\
\hline+ non-specific lipid transfer protein & $68.1 \pm 2.3$ & $18.1 \pm 5.1$ & $32.3 \pm 1.3$ \\
\hline
\end{tabular}

fusion, when this is determined on the basis of glycerol triolate and even $40 \%$ when cholesteryloleate is used as non-exchangeable marker. However, both markers are present in the same vesicle and if one assumes that the vesicle composition is homogeneous, the results indicate that no more than $25 \%$ of the PC increase in the erythrocytes can be ascribed to contamination or fusion. Another approach to discriminate between exchange, fusion and contamination is based on a combination of the use of non-exchangeable markers and a method which recognizes PC not incorporated in the lipid bilayer. We have used therefore the phospholipase $\mathrm{C}$ purified from Bacillus cereus which is unable to attack its substrate in intact red cell membranes [27], whereas the phospholipids in the vesicle bilayer will be readily degraded. In case of binding of intact vesicles to the erythrocytes, the PC in these vesicles will be easily hydrolyzed by the phospholipase and thus be detected as contamination. Erythrocytes, previously incubated with non-specific lipid transfer protein and vesicles containing ${ }^{14} \mathrm{C}$-labeled fatty acyl PC, were isolated and subsequently treated with phospholipase C. Indeed the PC molecules organized in the vesicles, are easily degraded by the phospholipase $\mathrm{C}$ and the radioactivity is recovered as diacylglycerol, whereas the PC molecules in the 'lipid-loaded' erythrocytes are not converted into radiolabeled diacylglycerol by the phospholipase $\mathrm{C}$ treatment (data not shown). These observations therefore obviously prove that the phosphatidylcholine, which is transferred from the donor vesicles to the erythrocyte by the nonspecific lipid transfer protein, is indeed incorporated into the bilayer rather than being present as vesicles, which adhere to the erythrocytes. Thus, it becomes clear from these experiments that both glycerol trioleate and cholesteryl oleate are inappropriate to detect a nonspecific adherence of the lipid vesicles to the red cell membrane in case of incubations with nonspecific lipid transfer protein.

The mechanism of this lipid transfer between donor and acceptor membranes is unknown. One of the possibilities, arising in particular from the data presented in Table II and the observations using phospholipase $\mathrm{C}$, could be that the nonspecific lipid protein mediates a fusion between the vesicles and the red cell membrane. The fact that the increases in the amounts of glycerol trioleate, cholesteryl oleate and phosphatidylcholine in the erythrocyte membrane are not identical indicates that fusion alone cannot account for the lipid transfer. In addition, the observation that sphingomyelin is transferred from the intact erythrocyte to the vesicles, does not support the occurrence of a fusion mechanism but suggests an actual lipid transfer. However, the most simple alternative explanation for the variation in the amounts of different lipids transferred to the erythrocytes could be that, in contrast to what is generally assumed, glycerol trioleate and cholesteryl oleate can be transferred by the particular nonspecific lipid transfer protein we used and 
cannot be, therefore, considered as 'non-exchangeable'.

\section{Discussion}

The data presented above indicate that the nonspecific lipid transfer protein can perform various functions. Of course, exchange of individual lipid molecules can be stimulated but the observations presented in Fig. 1 and Table I show that also net transfer of lipids is enhanced by the protein. The mechanism by which both events take place is unknown, be it that Nichols and Pagano [28] have suggested that nonspecific lipid transfer protein functions to increase spontaneous transfer processes by binding to the vesicles and nonspecifically enhancing the rate of monomer-vesicle dissociation and association. Adherence of vesicles to erythrocytes can be excluded (see Table II). Fusion may occur, be it that it cannot explain the transfer of PC completely.

The results of these studies demonstrate that the nonspecific lipid transfer protein is able to alter the content and composition of the lipids in the membrane of the intact erythrocyte. Therefore, the protein can be useful to modify normal erythrocytes so as to mimic abnormal red cells, which are often acquired in patients with a liver disease. These hemolytic syndromes are associated with a disordered plasma lipoprotein metabolism, inducing red cell modifications [29-36]. 'Spur' cells are such abnormal erythrocytes, which are characterized by an increased content of cholesterol and PC, be it that the total amount of phospholipids is comparable to that in normal erythrocytes $[23,29,33,36]$. Elevated amounts of $\mathrm{PC}$ and cholesterol are also found in the so-called 'target' cells. These red cells are characterized by their targeted appearance, due to an increased surface area induced by an elevated lipid content $[29,31,33,35]$. The amount of cholesterol may range between $25 \%$ and $75 \%$ above normal in these cells, whereas the enhancement in phospholipid content is approx. 60\%. Changes in phospholipid composition do not concern all phospholipids, but are usually confined to phosphatidylcholine [29,33]. Similar alterations in PC and cholesterol content can be induced in normal red cells by incubating them together with $\mathrm{PC} /$ cholesterol in the presence of nonspecific lipid transfer protein (Fig. 1 and Table I). Furthermore, shifts in the PC/sphingomyelin molar ratio can be easily induced by using nonspecific lipid transfer protein and vesicles containing variable amounts of these two phospholipids and cholesterol. A decrease in PC, which is compensated for by an increase in sphingomyelin, is observed in acanthocytes, a red cell abnormality occurring in patients with congenital Abetalipoproteinemia $[29,37]$.

Although variations in the amount of cholesterol in the red cell membrane can be obtained by in vitro incubations of the intact cells with vesicles containing either phospholipid or phospholipid/cholesterol, this technique does not allow a transfer of phospholipids to any significant extent [23-25,29,37]. Using the nonspecific lipid transfer protein it is possible now, to modify the following characteristics of the membrane of the intact erythrocyte: (i) the total lipid content, (ii) the cholesterol/phospholipid ratio, as well as (iii) the composition of the phospholipid fraction. Therefore, this protein can be used to modify normal red cells to such an extent, that their lipid composition and/or content resemble that of specific types of red cell abnormalities.

\section{Acknowledgements}

The present investigations were carried out under the auspices of The Netherlands Foundation for Chemical Research (S.O.N.), and with financial aid from The Netherlands Organization for Advancement of Pure Research (Z.W.O.).

\section{References}

1 Op den Kamp, J.A.F. (1979) Annu. Rev. Biochem. 48, 47-71

2 Van Meer, G., Poorthuis, B.J.H.M., Wirtz, K.W.A., Op den Kamp, J.A.F. and Van Deenen, L.L.M. (1980) Eur. J. Biochem. 103, 283-288

3 Van Meer, G. and Op den Kamp, J.A.F. (1982) J. Cell. Biochem. 19, 193-204

4 Franck, P.F.H., Chiu, D.T.Y., Op den Kamp, J.A.F., Lubin, B., Van Deenen, L.L.M. and Roelofsen, B. (1983) J. Biol. Chem. 258, 8435-8442

5 Crain, R.C. and Zilversmit, D.B. (1980) Biochemistry 19, 1440-1447

6 Bloj, B. and Zilversmit, D.B. (1977) J. Biol. Chem. 252, $1613-1619$ 
7 Crain, R.C. and Zilversmit, D.B. (1980) Biochemistry 19, 1433-1439

8 Poorthuis, B.J.H.M., Glatz, J.F.T., Akeroyd, R. and Wirtz, K.W.A. (1981) Biochim. Biophys. Acta 655, 256-261

9 Trzaskos, J.M. and Gaylor, J.L. (1983) Biochim. Biophys. Acta 751, 52-65

10 Bloj, B. and Zilversmit, D.B. (1981) J. Biol. Chem. 256, 5988-5991

11 Bloj, B. and Zilversmit, D.B. (1983) Methods Enzymol. 98, 574-586

12 Crain, R.C. and Zilversmit, D.B. (1980) Biochim. Biophys. Acta $620,37-48$

13 Zilversmit, D.B. (1983) Methods Enzymol. 98, 565-573

14 Crain, R.N. and Zilversmit, D.B. (1981) Biochemistry 20, $5320-5326$

15 North, P. and Fleischer, S. (1983) J. Biol. Chem. 1242-1253

16 Crain, R.C. (1982) Lipids 17, 935-943

17 Muczynski, K.A., Harris, W.F. and Stahl, W.L. (1981) Int. J. Biochem. 13, 959-963

18 Rose, H.G. and Oklander, M. (1965) J. Lipid Res. 6, 428-431

19 Rouser, G., Fleischer, S. and Yamamoto, A. (1970) Lipids $5,494-496$

20 Zlatskis, A., Zak, B. and Boyle, A.J. (1953) J. Lab. Clin. Med. 41, 486-492

21 Broekhuyse, R.M. (1969) Clin. Chim. Acta 23, 457-461

22 Little, C. Aurebekk, B. and Otnaess, A.B. (1975) FEBS Lett. $52,175-179$
23 Cooper, R.A., Arner, E.C., Wiley, J.S. and Shattil, S.J. (1975) J. Clin. Invest. 55, 115-126

24 Cooper, R.A., Leslie, M.H., Frischkoff, S., Shinitzky, M. and Shattil, S.J. (1978) Biochemistry 17, 327-331

25 Hui, S.W., Stewart, C.H., Carpenter, M.P. and Stewart, T.P. (1980) J. Cell Biol. 85, 283-291

26 Bell, F.P. (1978) Prog. Lipid Res. 17, 207-243

27 Roelofsen, B., Zwaal, R.F.A., Comfurius, P., Woodward, C.B. and Van Deenen, L.L.M. (1971) Biochim. Biophys. Acta 241, 925-929

28 Nichols, J.W. and Pagano, R.E. (1983) J. Biol. Chem. 258, 5368-5371

29 Cooper, R.A. (1980) Semin. Hematol. 17, 103-112

30 Neerhout, R.C. (1968) J. Lab. Clin. Med. 71, 438-454

31 Nye, W.H.R. and Marinetti, G.V. (1967) Prog. Exp. Biol. Med. 125, 1220-1224

32 Gjone, E., Torsevik, H. and Norum, K.R. (1968) Scan. J. Clin. Lab. Invest. 21, 327-332

33 Cooper, R.A., Diloy-Puray, M., Lando, P. and Greenberg, M.S. (1972) J. Clin. Invest. 51, 3183-3192

34 Cooper, R.A., Kimball, D.B. and Durocher, J.R. (1974) N. Engl. J. Med. 290, 1279-1284

35 Verkleij, A.J., Nauta, I.H.D., Werre, J.M., Mandersloot, J.G., Reinders, B., Ververgaert, P.H.J.T. and De Gier, J. (1976) Biochim. Biophys. Acta 436, 366-376

36 Cooper, R.A. (1969) J. Clin. Invest. 48, 1821-1831

37 Cooper, R.A., Durocher, J.R. and Leslie, M.H. (1977) J. Clin. Invest. 60, 115-121 